\title{
ETHOSUL MISIONAR AL BISERICII ÎN CONTEXTUL PROVOCĂRILOR BIOTEHNOLOGICE CONTEMPORANE
}

Cosmin Lazăr*

\begin{abstract}
Throughout its history, romanian Orthodoxy acquired a specific missionary ethos, which can not be understood without taking into account a number of theological concepts, religious institutions and social realities, such as: the local Church, the political symphony, autocephaly, asceticism and social philanthropy. Its missionary spirit was determined by historical circumstances, frequently disadvantageous, in which Orthodoxy was forced to concentrate on the internal pastoral and worship, to protect its members, without the freedom of a wide scope mission. Postmodernity, follower of a secular bioethics type, related to the concept of medical ethics, and a set of internal moral norms, sacrifice christian moral principles in a Lucifer manner of asserting and generalizing the performances of modern biotechnology, in this way causing destabilization of the inner man. That is why the church is called to defend person and human life and based on that recognition of the sanctity of human life prerequisite for respecting life and its being.
\end{abstract}

Key words: human autonomy, liberal eugenics, christian bioethics, in vitro fertilization, human enhancement, transhumanism.

\section{Preliminarii}

Omul post-modern îşi exercită în mod constant dorința de a îşi construi propriul destin, ignorând realităţile fundamentale ale vieții. Din căutare a lui Dumnezeu, omul a transferat sensul cunoaşterii în căutare împreună cu Dumnezeu, pentru ca în postmodernitate să-şi declare căutarea fără Dumnezeu.

\footnotetext{
* PhD candidate, "1 Decembrie 1918" University, Faculty of Orthodox Theology, Alba Iulia, Romania.
} 
În medicină se asistă la aplicarea dezechilibrată a descoperirilor ştiinţifice şi tehnologice precum şi la limitarea acțiunilor umane în hotărâri referitoare la existența biologică care relativizează viaţa, introducând în mentalul colectiv uman îndoiala, incertitudinea şi speranţe irealiste. Sub imperiul tehnicii biotehnologice din care "ştiința a făcut din noi zei, înainte de a merita să fim oameni" , ethosul moralei ortodoxe este chemat să valorifice importanța, prestigiul, autonomia şi valoarea persoanei umane, pentru că ,înlăuntrul conştiinței sale, în miezul experienței celei mai profunde, omul presimte a fi mai mult decât un simplu fenomen al lumii acesteia(...). El se descoperă ca fiind o persoană animată de lumină, de un har venind dintr-un altundeva"2. Viaţa din care lipseşte Dumnezeu este lipsită de sens şi de demnitate. Existența terestră are ea însăşi un caracter transcendent pentru că ea se împlineşte în viaţa veşnică. Hristos este Cel care conferă sens şi putere de a-L urma, Cel care transformă fundamental viața pământească în viață veşnică. Existența umană şi existența în general se bazează pe darul lui Dumnezeu, de aceea, "ea este hristocentrică, adică marcată de darurile dumnezeieşti ale înțelepciunii Fiului lui Dumnezeu"’3.

\section{Individualismul şi secularismul postmodern, agenții bioehnologiei contemporane}

Ignorând şi negând revelaţia divină precum şi relaţia directă dintre persoană şi Creator, postmodernitatea se relevează prin valorificarea excesivă a eu-lui uman hipertrofiat, postulând dezvoltarea acestuia în contextul mai larg al noilor cuceriri ale ştiinţei şi tehnologiei, în spirit secularizant şi globalizant. Sub aspect

\footnotetext{
${ }^{1}$ Sintagama aceasta apare pe frontispiciul „Revistei Române de Bioetică” şi aparține lui Jean Rostand (1894-1977) biolog şi filosof francez.

2 Olivier Clemént, Viața din inima morții, trad. Claudiu Soare, Târgovişte, Edit. Pandora, 2001, p. 87.

${ }^{3}$ Daniel Munteanu, Pe urmele iubirii. Contribuții trinitare la o cultură a comunicării sfințitoare, Târgoviş̦te, Edit. Bibliotheca, 2013, p. 319.
} 
definitoriu se poate afirma că "postmodernitatea este incredulitatea arătată meta-istoriei”"

Notele dominante ale postmodernității sunt date de expansiunea fără precedent a tehnologiei informației, accesul neîngrădit la date şi de rolul tot mai accentuat deținut de mass-media în formarea personalităţii umane. În aceeaşi ordine de idei se poate observa şi creşterea galopantă a gradului de accesibilitate a oamenilor la noile realizări ale progresului şi civilizației contemporane, în sensul în care un procent tot mai mare din populația planetei are acces la tehnologii şi biotehnologii de ultimă generație care urmăresc asiduu perfecționarea naturii umane ${ }^{5}$. Un alt factor care încurajează instalarea unei mentalități postmoderne în societate îl constituie progresul economic, generator de bunăstare materială fără preceden, aspect care se constată, mai ales în țările puternic dezvoltate, neafectate de războaie sau conflicte entice şi religioase.

Postmodernitatea s-a instalat pe fondul unui progres fără precedent al bunurilor de consum, asemenea hambarelor pline din Sfânta Evanghelie (Luca 12, 16-21), în detrimentul culturii spiritului, aflată într-un continuu şi constant regres. Totuşi, doi factori majori sunt extrem de proeminenți şi stau la baza procedeelor de natură biotehnologică:

1. Individualismul care "propovăduiește" cultivarea valorii exagerate a sinelui, în societatea postmodernă şi îi solicită omului să se afirme cu orice preț, căutând să se promoveze cât mai sus, pe scară ierarhică, la nivel economic, politic, cultural şi social. Aceasta presupune, în mod necesar, negarea identității primite la naştere, inclusiv în ceea ce priveşte apartenența religioasă. Se pune în valoare individul şi se abandonează persoana. Forța interioară nu se bazează pe echilibru, pe cunoaştere a realităților vieții, pe abandonarea în voia lui Dumnezeu ci dimpotrivă, forța omului postmodern rezidă

\footnotetext{
${ }^{4}$ Mirel Bănică, Locul celuilalt. Ortodoxia în modernitate, Bucureşti, Edit. Paideia, 2007, p. 121.

${ }^{5}$ Sharon Tamar, Human Nature in an Age of Biotechnology, Maastricht, Springer, 2014, pp. 61-63.
} 
tocmai în dezechilibrul său interior care îl determină să se abandoneze condiției stresante a vieții, pentru a scăpa de marile chestiuni existenţiale. Se află într-o depresie continuă, justificând existența unei pleiade de "psihologi" care îi "refac" echilibrul prin terapii de exacerbare a propriei personalități ${ }^{6}$. Se promovează şi se susține astfel cu înverşunare dreptul şi beneficiul absolut al individului în ceea ce priveşte procrearea biotehnologică cu negarea totală sau parţială a unei etici morale de tip creştin, ${ }^{7}$ în favoarea pluralismului moral şi a unei bioetici de tip secular care atentează în mod direct asupra moralei creştine în general şi a celei ortodoxe în $\bmod$ special ${ }^{8}$.

2. Secularismul, cel care neagă în mod violent şi vehement, exprimarea religiozității manifestând dezacord față de Biserica tradițională:

"Într-o pluritate morală care se desfăşoară în contextul amplificării constante a inabilității culturii seculare dominante, de a justifica o morală particulară plină de conținut, umanitatea se află înconjurată de pespective morale aparent ireductibile. În ciuda unor proclamări pline de patos privind existența consensului moral, realitatea contemporană este marcată de dezacorduri, dar şi de incapacitatea identificării modului în care, folosindu-se de o argumentație solidă şi rațională, diversitatea morală poate fi depăşită"9.

\footnotetext{
${ }^{6}$ Mihail Neamţu, Gramatica Ortodoxiei, Tradiţia după modernitate, Iaşi, Edit. Polirom, 2007, pp. 40-41.

${ }^{7}$ Nicholas Capaldi, The New Age, Christianity and Bioethics, în „Christian Bioethics", 8. 3, 2002, pp. 283-284.

${ }^{8} \mathrm{H}$. Tristram Engelhardt jr., Moral pluralism, the crisis of secular bioethics, and the divisive character of christian bioethics: taking the culture wars seriously, în „Christian Bioethics”, 15. 3, 2009, pp. 234-235.

${ }^{9}$ Corinna Delkeskamp-Hayes, Moralitatea intr-o lume postmodernă, postcreştină: diagnosticul şi terapia ei în viziunea lui Engelhardt, trad. Iulian Aniței, în Ana Smith Iltis, Mark J. Cherry, (ed.), „La temeliile bioeticii crestine. Eseuri critice asupra gândirii lui H. Tristram Engelhardt Jr.”, ClujNapoca, Edit. Renaşterea, 2011, p. 51.
} 


\section{Biotehnologizarea naturii umane}

Omul şi-a dorit întotdeauna mai mult: mai multă putere, mai multă cunoaştere mai multă voință, mai multă libertate. Actor pe scena lumii descătuşate, omul caută soluții imediate, în condițiile în care transcendentul este prea departe, iar divinitatea nu se pare a se manifesta concret în viaţa lui, considerând că descoperirea "tainelor vieții umane" îi oferă şansa să îndrepte ceea ce se naşte defect sau diform. Absența lui Dumnezeu şi a dimensiunii metafizice a existenției îl înalță pe om în vârful piramidei oferindu-i autonomia cvasitotală a cunoaşterii genomului uman prin care pătrunde în structura intimă a ființei proclamând transumanismul ${ }^{10}$ şi sfârşitul umanității, în favoarea lui homo fabricatus ${ }^{11}$.

Autonomia crescândă a puterii omului în fața puterii supranaturale, oferită de revoluțiile tehnice, atentează în mod direct şi flagrant asupra demnităţii umane ${ }^{12}$. Dezvoltarea fără precedent a tehnologiilor biomedicale, în mod special în ultimele trei decenii, a făcut ca omul modern să se situeze în fața unor întrebări, care vizează etica şi moralitatea existenței, o viață aşezată azi, datorită dezvoltării biotehnologice la intersecția deciziei umane. O privire complementară certifică faptul că sensul pozitiv sau negativ este conferit de conştiinţa şi libertatea persoanei umane, căreia i se cere astăzi să decidă acolo unde "ieri nu era nevoie". O conştiință

\footnotetext{
${ }^{10}$ Transumanismul urmăreste depăşirea umanului actual prin recurs la ştiințele şi tehnologiile avansate, susţinându-se că este posibil reconfigurarea naturii umane şi crearea unor ființe superioare lui homo sapiens din punct de vedere biologic şi tehnologic; a se vedea în acest sens Ioan Zane, Iustin Lupu, Oana Mureşan, Bioetica şi provocările ştiinței, în „Revista Română de Bioetică", vol. 8, nr. 4, 2010, pp. 39-40.

${ }^{11}$ Nicholas Agar, Humanity's End: Why We Should Reject Radical Enhancement, Hardcover, Massachusetts, 2010, pp. 17-35.

${ }^{12}$ Olivier Riaudel, La dignité de la personne humaine, în „Revue d'Éthique et de Théologie Morale", nr. 249, 2008, pp. 38-50.
} 
ancorată în transcendental şi o libertate exercitată într-un sens creştin şi evanghelic va putea lua întotdeauna o decizie pozitivă ${ }^{13}$ şi morală.

Una dintre justificările continuării dezvoltării biotehnologiei este dorința morală şi corectă până la un anumit punct de prelungire a stării de sănătate şi a vieții, în beneficiul propriu şi cel al familiei, de sporire a confortului fizic, de eradicare a suferinței fizice şi psihice, chiar dacă nu există nici un motiv de a presupune că cercetătorii se vor opri atunci când vor obține o durată de viaţă medie de 140 sau 180 de ani ${ }^{14}$. Viziunea postmodernităţii este una a minimalismului etic, situat în "amurgul datoriei şi în sfera postmoralismului"15. Omenirea este la răspântie, iar bioetica ca ştiință de graniță se situează în avangarda noului umanism, prinsă între nevoia de teoretizare a demnitătiii speciei umane şi cea de prefigurare a sensurilor transumaniste ${ }^{16}$ şi a eliberării de sub imperiul selecției naturale.

\section{Screening-ul genetic şi diagnosticul prenatal}

Screeningul genetic, este o metodă de studiu populațional ce identifică genotipurile asociate cu o anumită afecțiune sau dispoziție la boală. De asemenea această metodă se poate aplica şi fătului uman pentru depistarea unor malformații congenitale ${ }^{17}$. Acesta are ca scop pe de o parte diferențierea subiecților în două categorii populaţionale, în persoane care poartă boala genetică şi persoane care posedă gena mutantă, iar pe de altă parte se urmăreşte

\footnotetext{
${ }^{13}$ Dónal P. O'Mathúna, Christian bioethics and the Bible, în „Christian Bioethics", 20. 2, 2014, pp. 247-259.

${ }^{14}$ Elena Moldovan, Biotehnologia şi căutarea perfecțiunii-corpuri fără vârstă, în „Revista Română de Bioetică”, vol. 3, nr. 2, 2005, p. 78.

${ }^{15}$ Antonio Sandu, Provocări bioetice în postmodernitate, în „,Revista Română de Bioetică", vol. 10, nr. 1, 2012, p. 3.

${ }^{16} \mathrm{M}$. J. McNamee and S. D. Edwards, Transhumanism, medical technology and slippery slopes, în „Journal of Medical Ethics”, 32.9, 2006, pp. 514-518.

${ }^{17}$ Claudiu Mărginean, et all., Ethical considerations in screening and ultrasound diagnosis of fetal heart defects, în „Revista Română de Bioetică vol. 12, nr. 4, 2014, p. 121.
} 
identificarea unor categorii populaționale cu predispoziție la asemenea boli. Finalitatea acestei identificări reprezintă de fapt alegerea unei "opțiuni reproductive optime", în deplină cunoştință de cauză şi acolo unde este posibil un tratament precoce ${ }^{18}$. Acest tip de de decodificare a genomului uman ${ }^{19}$ este folosit şi pentru sudiul impactului pe care medicamentele le au asupra organismului uman sau pentru depistarea anumitor boli genetice în neonatologie ${ }^{20}$.

Diagnosticul prenatal este utilizat în cazul sarcinilor cu risc crescut. De aceea se impune conform eticii medicale consilierea genetică a cuplului sau a părinţilor în condiţiile în care este nevoie de consultări interdisciplinare între obstretician, pediatru, genetician şi neonatolog. Bolile cromosomice ${ }^{21}$ sunt cele care pot determina severitatea malformației. În urma obținerii unui diagnostic clar, ultima decizie rămâne în mâinile părinților care pot sau nu, să ia hotărârea de a apela la un avort. Este de menționat faptul că atât testul genetic, cât şi cel prenatal ridică probleme etice, psihologice, legislative dar şi morale, în condițiile care se poate apela la avort ca metodă terapeutică aşa cum încearcă să justifice acceptarea lui cei care pun pe primul plan, dreptul şi beneficiul personal al mamei ${ }^{22}$.

${ }^{18} \mathrm{~J}$. Kaye and Anneke Lucassen, Genetic testing without consent: the implications of the new human tissue Act 2004, în „Journal of Medical Ethics”, 32.12, 2006, pp. 690-692.

${ }^{19}$ Genomul reprezintă întreaga informație ereditară a unui organism, incluzând genele şi secvențele noninformaţionale ale ADN-ului şi anume intronii, a se vedea pe larg Daniela Neagoş, Genetica umană. Suport de curs, Bucureşti, Edit. All, 2013.

${ }^{20}$ Mircea Gelu Buta, Iulia Alexandra Buta, Bioetica între mărturisire şi secularizare, Cluj-Napoca, Edit. Renaşterea, 2008, pp. 206-207.

${ }^{21}$ Lavinia Caba, Monica Pânzaru, Diagnostic prenatal invaziv versus noninvaziv: controverse şi dileme etice, în „Revista Română de Bioetică”, vol. 10, nr. 3, 2012, pp. 30-31.

${ }^{22}$ D. Heyd, Prenatal diagnosis: whose right?, în ,Journal of Medical Ethics”, 21.5, 1995, pp. 296-297. 
2. Embrionul uman şi pericolul tehnicizării ființei umane

Termenul de procreație a apărut ca rezultat al aplicării noilor tehnologii de reproducere medical asistată şi apariției unor noi noțiuni: donatori de gameți, bănci de spermă, donatori de embrioni, maternitate de substituție sau mamă surogat. Apariția conceptului de "familie genetică" a bulversat întreaga cultură şi societate iar statutul embrionului uman aflat în centrul noilor tehnologii reproductive a ridicat o serie de probleme morale, medicale, filosofice şi ontologice $^{23}$. Se cunoaşte faptul că pentru fertilizarea in vitro, sunt recoltate şi fecundate mai multe ovule, deşi proiectul are în vedere conceperea unui singur copil. Trebuie amintit faptul că embrionul nu este numai expresia genetică şi completă a ființei umane, el reprezentând şi un puternic simbol al regenerării umane ${ }^{24}$. Aici intervine problema "embrionilor numerali" care din păcate vor fi distruşi la dorința părinţilor sau vor fi folosiți în experimente de laborator, ${ }^{25}$ sau chiar crilogenaţi pentru a fi implantați unei alte femei în urma încheierii unui contract între donator şi primitor ${ }^{26}$. În aceeaşi ordine de idei se poate aminti folosirea mamei surogat sau a mamei de substituție chestiune care implică riscuri imense din punct de vedere social, psihologic şi moral. Ce se va întâmpla dacă se naşte un copil cu handicap şi mama biologică nu îl acceptă? Cum se rezolvă problema dacă mama purtătoare refuză să cedeze copilul? Sunt încălcate drepturile şi libertăţile copilului, dacă el va avea o mama biologică, o mamă purtătoare şi o mamă socială? Nu cumva se

\footnotetext{
${ }^{23}$ Roxana Folescu, Ethical considerations regarding the moral status of the human embryo, în „Revista Română de Bioetică”, vol. 12, nr.4, 2014, p. 49.

${ }^{24}$ Mircea Gelu Buta, Iulia Alexandra Buta, op. cit., p. 186.

${ }^{25}$ Aaron Hinkley, In Vitro fertilization, double efect and stem cell research: an introduction, în „Christian Bioethics”, 18. 3, 2012, pp. 231-232.

${ }^{26} \mathrm{G}$. Pennings, The validity of contracts to dispose of frozen embryos, în „Journal of Medical Ethics”, 28. 5, 2002, pp. 296-298. 
asistă aici la tulburări grave în ceea ce privesc relaţiile maternale şi cele de filiație ${ }^{27}$ ?

Biotehnologia embrionară nu se dezminte nici atunci când recurge la cercetarea pe embrioni umani cu scop exclusiv ştiinţific. Astfel se recurge la experimente de tip farmacologic sau genetic asupra embrionilor vii sau morți. Este de remarcat faptul că experimentele embrionare utilizează şi celulele stem embrionare ${ }^{28}$ în vederea prelevării de țesuturi fetale în scopul transplantului de măduvă osoasă, de celule nervoase, hepatice sau pancreatice ${ }^{29}$.

Problema morală pe care o ridică această chestiune este legată de faptul că recoltarea acestor celule produce moartea embrionilor, deci omucidere ${ }^{30}$. Desigur că toate aceste aspecte legate de experimentarea, manipularea şi utilizarea embrionului uman prezintă profunde implicații de natură socială, morală şi legislativă, care atentează într-un fel sau altul la autonomia umană şi la identitatea naturii umane, care devine din ce în ce mai tehnologizată şi programată să devină "mai bună".

3. Eugenismul, "human enhancement" şi transumanisul, un deziderat al postmodernității

Proiectul de îmbunătăţire al rasei umane care poate fi

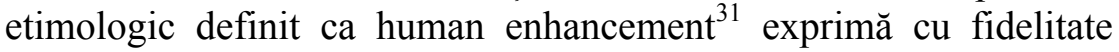
intenția bioeticii seculare în ceea ce priveşte creşterea nivelului de

${ }^{27}$ Mark A.Tarpley, The christian family crisis in the United States and its implications for medical decision making, în „Christian Bioethics”, 7. 3, 2011, pp. 299-310.

${ }^{28}$ Sabin Guțan, Reproducerea umană asistată medical şi filiația, Bucureşti, Edit. Hamangiu, 2011, pp. 16-23.

${ }^{29} \mathrm{M}$. R. Green, 10 years of stem cells embryo as epiphenomenon: some cultural, social and economic forces driving the stem cell debate, în ,Journal of Medical Ethics", 34. 12, 2012, pp. 841-842.

${ }^{30}$ Juvenalie Ionaşcu, Teroriştii uterului. Terorism ştiințific şi etica începuturilor vieții, Eseu de bioetică a gestației, Bucureşti, Edit. Anastasia, 2002, pp. 259261.

${ }^{31}$ Michael J. Selgelid, Freedom and moral enhancement, în „Journal of Medical Ethics", 40. 4, 2014, pp. 215-216. 
calitate al rasei umane precum şi eradicarea dizabilităților umane încă din perioada prenatală.

Eugenismul ( $\varepsilon v \gamma \varepsilon v \eta \varsigma$-naştere bună) a fost teoretizat pentru prima dată la sfârşitul secolului al XIX-lea de către englezul Francisc Galton $^{32}$ (1822-1911) în anul 1883. În principiu se dorea a fi ştiința naşterilor bune, regimul nazist s-a folosit de el într-un scop atroce şi rasial.

În mod paradoxal, societatea contemporană se confruntă cu o dilemă majoră: pe de o parte ea are responsabilitatea de a se îngriji de persoanele cu dizabilități, iar pe de altă parte politicile sociale din ultimele decenii au ca deziderat reducerea sau evitarea dizabilităţii ${ }^{33}$. Practic dezvoltarea biotehnologică, pune în mâna omului noi instrumente tehnice în vederea dezvoltării practicilor de tip eugenic $^{34}$. Pacticile eugenice din primele decenii ale secolului al XX-lea, aveau ca intenție prevenirea reproducerii ființelor umane considerate neadecvate din punct de vedere genetic prin încurajarea de a alege partenerul în conformitate cu standarde determinate sau prin sterilizarea obligatorie a pacienților cu boli mintale. Astăzi din fericire nu se mai poate vorbi despre o asemenea politică socială, dar iată că la porțile inteligentei umane se manifestă o tot mai mare dorință pentru eugenia liberală $\breve{~}^{35}$, cu referire directă la îmbunătățirea genetică necoercitivă, care nu ar reduce autonomia umană, aşa cum susțin adepții acesteia. Acest tip de eugenie se referă la alegerile făcute de părinți asupra viitorilor lor copii, subestimându-se total implicațiile de natură morală şi emoțională care se vor manifesta în

\footnotetext{
${ }^{32} \mathrm{~A}$ se vedea activitatea şi principiile sale eugenice în Nicholas Wright Gillham, A life of Sir Francis Galton from African exploration to the birth of eugenics, New York, Oxford University Press, 2001.

${ }^{33}$ Reindal Magnus Solveig, Disability, gene therapy and eugenics- a challenge to John Harris, în ,Journal of Medical Ethics”, 26. 2, 2000, pp. 93-94.

${ }^{34}$ Maria Aluaş, Eugenismul contemporan intre realizarea dorințelor şi prevenirea dizabilităților, în „Studia Universitatis Babeş-Bolyai, Bioethica”, vol. LVIII, nr. 1, 2013, p. 72.

${ }^{35} \mathrm{~A}$ se vedea pe larg Nicholas Agar, Liberal Eugenics. In defence of human enhancement, Malden, Blackwell Publishing, 2004.
} 
viața lor mai târziu ${ }^{36}$. În altă ordine de idei, ea este rezervată familiilor cu potențial financiar ridicat, care doresc să aibă un copil conform dorinței lor, frumos, capabil, inteligent şi care să aibă succes într-o societate foarte competitivă si standardizată. Ideea de a îmbunătăți capacitatea copilului încă din faza prenatală arată cât de mult societatea este influențată de condiționările standardelor sănătăţii. În societatea publică prinde rădăcini "dorința" părinților de a avea un "copil dotat" ". Bineînțeles că o asemenea mentalitate utilitaristă, a copiilor "comandați", nu anticipează sau ignoră repercursiunile morale, psihologice şi sociale pe care aceşti copii vor fi nevoiţi să le suporte în viețile lor de adulți chiar dacă nu au avut nici un rol în decizia de a fi "creați mai buni"

Postumanismul sau transumanismul în context biotehnologic constituie tehnologizarea la maxim a ființei umane şi constă în dorința exacerbată de creare a unei rase umane superioare, un homo fabricatus ${ }^{39}$. El este definit ca: "o mişcare culturală şi intelectuală internațională care susține utilizarea noilor tehnologii biomedicale pentru intensificarea capacităţilor umane cognitive şi fizice şi pentru ameliorarea aspectelor nedorite ale condiției umane cum sunt boala, îmbătrânirea şi moartea", după cum mărturiseşte filosoful suedez Nick Bostrom ${ }^{40}$, un cunoscut promotor şi suș̦inător al acestuia. Afirmațiile transumaniste presupun un proces de transformare umană prin tehnologie fără a specifica un scop sau un stadiu final, ele rezumându-se a vorbi despre schimbări ireversibile. Anumite aspecte ale naturii umane sunt menționate în mod constant:

\footnotetext{
${ }^{36}$ Russell Powell, The biomedical enhancement of moral status, în ,Journal of Medical Ethics", 39. 2, 2013, pp. 65-66.

${ }^{37}$ Maria Aluaş, art. cit., p. 73.

${ }^{38}$ Beatrice Ioan, Diana Blugaru, Cristina Gavrilovici, Vasile Astărăstoaie, Copilul perfect între vis şi realitate. Implicații etice ale noilor teorii genetice în imbunătățirea calităţilor umane, în Mircea Gelu Buta (coord.), „Medicii şi Biserica", vol. IV, Cluj-Napoca, Edit. Renaşterea, 2006, p. 169.

${ }^{39}$ Bert Gordijt, Ruth Chadwich, Medical Enhancement and Posthumanity, Maastricht, Springer, 2008, pp. 95-100.

${ }^{40} \mathrm{http}: / /$ www.nickbostrom.com/old/transhumanism.html accesat în (27.04. 2015).
} 
durata vieții umane, îmbunătăţirea abilităților mentale sau a capacităților fizice ${ }^{41}$ care în mod evident ascund pericolul geneticizării şi al dezumanizării. Acesta rezidă în principal dintr-un mod de gândire reducţionist în care condiția umană, valorile sociale sunt privite, abordate şi explicate prin prisma ereditătiii, accentul fiind pus pe determinarea genetică. Probleme precum personalitatea, autonomia, responsabilitatea, obezitatea sau homosexualitatea sunt puse în principal pe seama $\mathrm{ADN}$-ului fiecărei persoane ${ }^{42}$.

Toate aceste date ilustrează faptul că progresul științelor biomedicale oferă umanității, pentru prima dată în istoria ei, posibilități reale de a controla procreația, ereditatea, gândirea şi comportamentul. Ele deschid spații de acțiune noi, dar creează totodată multiple dileme, situații complicate de alegere şi decizie, cu repercursiuni din cele mai grave.

\section{Ethosul bioeticii ortodoxe}

Societatea contemporană se confruntă cu o relativizare a valorilor ce implică mai multe aspecte: pe de-o parte există valori care sunt aproape uitate - precum respectul, ascultarea, smerenia, puritatea - deoarece ele sunt considerate a fi depăşite şi ridicole pentru omul postmodern, iar pe de altă parte tot mai des se insistă pe promovarea "valorilor" precum: emanciparea, libertatea, democrația, autonomia sau progresul, ca expresie a comportamentului moral fundamentat pe tendința de eludare şi îndepărtare a substratului religios, şi a actului moral, impunând astfel lejeritatea comportamentală ${ }^{43}$.

“Trăim într-o epocă în care responsabilitatea morală este devalorizată şi golită de sens, e considerată desuetă şi aşezată între reperele tradiţionaliste.

${ }^{41}$ Ioan Chirilă, În-singurarea- Telos-ul unei lumi fără sens, în „Studia Universitatis Babeş-Bolyai Bioethica", vol. III, nr. 1, 2008, pp. 4-5.

${ }^{42}$ Ioan Zanc, Iustin Lupu, Oana Mureşan, Bioetica şi provocările ştiinție, în „Revista Română de Bioetică, vol. 8, nr. 4, 2010, p. 42.

${ }^{43}$ Bogdan Bunescu, Morala creștină in societatea postmodernă, în „Studia Doctoralia Andreiana", anul II, nr. 1, Sibiu, Edit. Andreiană, 2013, p. 98. 
În contextul rapidelor modificări de mentalitate, e necesar să regândim valoarea şi specificul responsabilității morale a persoanelor şi a grupurilor umane, chiar a societăților în sensul foarte larg al termenului, în spațiul ideologic cultural şi social românesc, încă destul de bine ancorat în valori creştine, dar cu tendințe clare de pierdere a lor, mai ales sub influențele tot mai concret simţite ale globalizării şi secularizării. Aceasta, cu atât mai mult cu cât adevărata soluție pentru societatea românească, adevăratele ei valori, adevărata venire întru sine, nu se pot redescoperi fără regenerarea morală, a cărei realizare îi aparţine în egală măsură, persoanei şi comunității, creştinului şi Bisericii" .

În acest context misiunea Bisericii trebuie să se axeze pe diversificarea ethosului eclesial si misionar care să promoveze constant, viguros şi variat, învățătura creştină cu referire la valoarea vieții umane, prin propovăduirea valorilor esențiale revelate, practicate între creştini, care îl transformă spiritual pe om, depăşind accentuarea materialismului şi importanţa exagerată a trupului, a vieții terestre şi a transformărilor exterioare. Caracteristic ethosului bioetic ortodox sunt abordările care evidenţiază demnitatea persoanei umane, importanța vieții biologice în relație cu viaţa veşnică, caracterul personal al relațiilor interumane ${ }^{45}$, precum şi valoarea omului în calitatea sa de subiect în relația cu transcendentul. Este imperios necesar să se accentueze următoarele elemente ca expresie a ethosului moral ortodox:

1. Prezența lui Dumnezeu în lume şi în om este o prezență plenară, definitorie şi concretă, ca valoare în sine şi reper pentru întreaga creație. Recunoaşterea prezenței divine ca manifestare dinamică produce efectul instaurării raporturilor de credinţă, morale şi practice dintre om şi Dumnezeu, dinte om şi om, dintre om şi creație, ele repercutându-se cu atât mai mult în domeniul bioeticii unde fiecare relaţie interumană este morală: ,O bioetică religioasă, în sensul unei bioetici întemeiate pe recunoaşterea sau experienţa unui Dumnezeu transcendent şi pe obligațiile faţă de acest

${ }^{44}$ Ştefan Iloaie, Responsabilitatea morală personală şi comunitară, ClujNapoca, Edit. Renaşterea, 2009, p. 18.

${ }^{45}$ A. Stephen, Erickson On the christian in christian bioethics, în „Christian Bioethics",1. 3, 2005, p. 273. 
Dumnezeu, oferă posibilitatea unei ancore adânci pentru o morală cu conținut" ${ }^{\prime 4}$.

2. Viaţa este prețiosul dar al Creatorului pentru umanitate, concept care cuprinde în sine şi viața spirituală, incomensurabil mai importantă decât viaţa biologică atât de mult biotehnologizată în societatea postmodernă. Afirmarea valorii vieții solicită în sens creştin o atitudine de prețuire şi ocrotire, demnitate rezultată din prezența lui Dumnezeu în ea, dar şi recunoaşterea scopului ei ultim: îndumnezeirea ${ }^{47}$.

3. Dragostea divină şi cea creştină afirmă de la naştere şi până la moarte existența în fiecare persoană a chipului Creatorului. Bioetica ortodoxă este iubirea vieții ${ }^{48}$ şi exprimă compasiunea, gentilețea, solicitudinea maximă şi compasiunea. În fiecare persoană este Hristos Însuşi. Iubindu- L pe El şi omul va fi iubit.

4. Omul-persoană este subiectul relațiilor cu divinitatea, dar şi subiectul bioeticii ortodoxe $e^{49}$ in contextul afirmării antropologiei ortodoxe. Este vorba de ceea ce Christos Yannaras numeşte "o aventură existențială a libertății noastre”, mai exact o libertate trăită în Dumnezeu şi pentru Dumnezeu prin puterea Sfântului Duh. "Din această pespectivă, bioetica este o ştiință esențial teologică, sensul însuşi al existenței umane găsindu-se în theosis, comuniunea veşnică cu cele trei Persoane ale Sfintei Treimi, comuniune ce ghidează toate relațiile interumane" ${ }^{, 50}$.

\footnotetext{
${ }^{46} \mathrm{H}$. Tristram Engelhardt jr., Fundamentele bioeticii creştine, perspectiva ortodoxă, trad. Mihail Neamțu şi Cezar Login, Sibiu, Edit. Deisis, 2005, p. 28. ${ }^{47}$ John Breck, Darul sacru al vieții. Tratat de bioetică, trad. de Irineu Pop Bistrițeanul, Cluj-Napoca, Edit. Renaşterea,, 2003, pp.15-16.

${ }^{48}$ Pavel Chirilă, Lucian Gavrilă, Cristina Gavrilovici, Andreea Băndoiu, Principii de bioetică, o abordare ortodoxă, Bucureşti, Edit. Christiana, 2008, p. 20.

${ }^{49}$ George Eber, Orthodox christian bioethics, în „Christian Bioethics”, 1. 2, 1995, pp. 128-132.

${ }^{50}$ Dominique Beaufils, Boris Bobrinscoy, John Breck, et all., Bioetica şi taina persoanei, trad. Nicoleta Petuhov, Bucureşti, Edit. Bizantină, 2006, p. 58.
} 


\section{Concluzii}

Prin intervenția în materialul genetic şi prin modificarea lui pot lua naştere pericole biologice, ecologice şi sociale imprevizibile, care nu sunt contrabalansate nicidecum de efecte binefăcătoare. Este nevoie de timp şi cercetare multilaterală pentru evaluarea şi folosirea realizărilor ştiinţifice, iar amestecul intereselor politice şi economice îmbinate $\mathrm{cu}$ trufia cunoaşterii umane, grăbesc şi simplifică procedurile, ducând la stări negative, alunecându-se astfel pe pante periculoase şi ireversibile. Denaturându-se ca persoană, omul prins în mrejele seducătoare al tehnicii devine sclavul bucuriilor aparente şi al surogatelor pe care i le oferă cunoaşterea biotehnologică seducătoare, creându-i mirajul unui confort calitativ a vieții biologice.

În ultimă instanță ethosul misionar al Bisericii face apel imperativ la responsabilitatea morala a persoanei umane, pentru că singurele îngrădiri substanțiale şi cu adevărat eficiente pentru om sunt cele de ordin moral pe care el însuşi şi le formează în interiorul ființei sale. $\mathrm{Cu}$ perspectiva ei teologică, morală şi patristică, bioetica ortodoxă are menirea şi responsabilitatea de a reaşeza în centrul acestor probleme biotehnologice contemporane, adevărul ființei şi al persoanei umane prin proclamarea voinței Dumnezeului Treimic care doreşte să-Şi aducă creația la desăvârşire şi îndumnezeire.

\section{Bibliografie:}

1. Agar, Nicholas, Liberal Eugenics. In defence of human enhancement, Malden, Blackwell Publishing, 2004.

2. Idem., Humanity's End: Why We Should Reject Radical Enhancement, Hardcover, Massachusetts, 2010.

3. Aluaş, Maria, Eugenismul contemporan intre realizarea dorințelor şi prevenirea dizabilităților, în „Studia Universitatis Babeş-Bolyai, Bioethica", vol. LVIII, nr. 1, 2013, pp. 71-87.

4. Bănică, Mirel, Locul celuilalt- Ortodoxia in modernitate, Bucureşti, Edit. Paideia, 2007. 
5. Beaufils, Dominique, Bobrinscoy, Boris, Breck, John et all., Bioetica şi taina persoanei, traducere din limba franceză de Nicoleta Petuhov, București, Edit. Bizantină, 2006.

6. Breck, John, Darul sacru al vieții. Tratat de bioetică, traducere din limba engleză de Irineu Pop Bistrițeanul, Cluj-Napoca, Edit. Renaşterea, 2003.

7. Bunescu, Bogdan, Morala creştină în societatea postmodernă, în „Studia Doctoralia Andreiana”, anul II, nr. 1, Sibiu, Edit. Andreiana, 2013, pp. 90-102.

8. Buta, Gelu Mircea, Buta, Alexandra Iulia, Bioetica între mărturisire şi secularizare, Cluj-Napoca, Editura Renaşterea, 2008.

9. Caba, Lavinia, Pânzaru, Monica, Diagnostic prenatal invaziv versus noninvaziv: controverse şi dileme etice, în „Revista Română de Bioetică", vol. 10, nr. 3, iulie-septembrie, 2012, pp. 29-37.

10. Capaldi, Nicholas, The New Age, Christianity and Bioethics, în „Christian Bioethics”, 8.3, 2002, pp. 283-294.

11. Chirilă, Ioan, În-singurarea- Telos-ul unei lumi fără sens, în „Studia Universitatis Babeş-Bolyai, Bioethica", vol. III, nr. 1, 2008, pp. 3-9.

12. Chirilă, Pavel, Gavrilă, Lucian, Gavrilovici, Cristina, Băndoiu, Andreea, Principii de bioetică, o abordare ortodoxă, Bucureşti, Edit. Christiana, 2008.

13. Clemént, Olivier, Viața din inima morții, traducere din limba franceză de Claudiu Soare, Târgovişte, Edit. Pandora, 2001.

14. Delkeskamp-Hayes, Corinna, Moralitatea intr-o lume postmodernă, postcreştină: diagnosticul şi terapia ei în viziunea lui Engelhardt, în Ana Smith Iltis, Mark J. Cherry, (ed.), „La temeliile bioeticii creştine. Eseuri critice asupra gândirii lui H. Tristram Engelhardt Jr.", ClujNapoca, Edit. Renaşterea, 2011, pp. 51-107.

15. Eber, George, Orthodox christian bioethics, în „Christian Bioethics”, 1. 2, 1995, pp. 128-152.

16. Erickson, A. Stephen, On the christian in christian bioethics, în „Christian Bioethics”,1. 3, 2005, pp. 269-279.

17. Engelhardt, H. Tristram jr., Fundamentele bioeticii creştine, perspectiva ortodoxă, traducere din limba engleză de Mihail Neamţu şi Cezar Login, Sibiu, Edit. Deisis, 2005.

18. Idem., Moral pluralism, the crisis of secular bioethics, and the divisive character of Christian bioethics: taking the culture wars seriously, in „Christian Bioethics”, 15.3, 2009, p. 234-253.

19. Folescu, Roxana, Ethical considerations regarding the moral status of the human embryo, în „Revista Română de Bioetică”, vol. 12, nr. 4, 2014, pp. 48-53. 
20. Gillham, Wright Nicholas, A life of Sir Francis Galton from African exploration to the birth of eugenics, New York, Oxford University Press, 2001.

21. Gordijt, Bert and Chadwich, Ruth, Medical Enhancement and Posthumanity, Maastricht, Springer, 2008.

22. Green, R. M., 10 years of stem cells embryo as epiphenomenon: some cultural, social and economic forces driving the stem cell debate, in „Journal of Medical Ethics”, 34. 12, 2012, pp. 840-844.

23. Guțan, Sabin, Reproducerea umană asistată medical şi filiația, Bucureşti, Editura Hamangiu, 2011.

24. Heyd, D., Prenatal diagnosis: whose right?, in „Journal of Medical Ethics", 21.5, May, 1995, pp. 292-297.

25. Hinkley, Aaron, In Vitro fertilization, double efect and stem cell research: an introduction, in „Christian Bioethics”, 18. 3, 2012, pp. 231-234.

26. Iloaie, Ştefan, Responsabilitatea morală personală şi comunitară, Cluj-Napoca, Edit. Renaşterea, 2009.

27. Ionaşcu, Juvenalie, Terorişstii uterului. Terorism ştiințific şi etica începuturilor vieții, Eseu de bioetică a gestației, Bucureşti, Editura Anastasia, 2002.

28. Ioan, Beatrice, Blugaru, Diana, Gavrilovici, Cristina, Astărăstoaie, Vasile, Copilul perfect între vis şi realitate. Implicații etice ale noilor teorii genetice în imbunătățirea calităților umane, în Mircea Gelu Buta (coord.), „Medicii şi Biserica”, vol. IV, Cluj- Napoca, Edit. Renaşterea, 2006.

29. Kaye, J., Lucassen, Anneke, Genetic testing without consent: the implications of the new human tissue Act 2004, în ,Journal of Medical Ethics", 32.12, 2006, pp. 690-692.

30. Mărginean, Claudiu et all., Ethical considerations in screening and ultrasound diagnosis of fetal heart defects, în „Revista Română de Bioetică”, vol. 12, nr. 4, 2014, pp. 120-125.

31. McNamee, M. J. and Edwards, S. D., Transhumanism, medical technology and slippery slopes, în „Journal of Medical Ethics”, 32.9, 2006, pp. 513-518.

32. Moldovan, Elena, Biotehnologia şi căutarea perfecțiunii-corpuri fără vârstă, în „Revista Română de Bioetică”, vol. 3, nr. 2, 2005, pp. 4044.

33. Munteanu, Daniel, Pe urmele iubirii. Contribuții trinitare la o cultură a comunicării sfințitoare, Târgovişte, Edit. Bibliotheca, 2013.

34. Neagoş, Daniela, Genetica umană. Suport de curs, Bucureşti, Edit. All, 2013. 
35. Neamțu, Mihail, Gramatica Ortodoxiei, Tradiția după modernitate, Iaşi, Edit. Polirom, 2007.

36. Pennings, G., The validity of contracts to dispose of frozen embryos, in ,Journal of Medical Ethics”, 28. 5, 2002, pp. 295-298.

37. Powell, Russell, The biomedical enhancement of moral status, in „Journal of Medical Ethics”, 39. 2, 2013, pp. 65-66.

38. Riaudel, Olivier, La dignité de la personne humaine, în „Revue d'Éthique et de Théologie Morale", nr 249, 2008, pp. 37-52.

39. Sandu, Antonio, Provocări bioetice în postmodernitate, în „Revista Română de Bioetică", vol. 10, nr. 1, 2012, pp. 3-4.

40. Selgelid, J. Michael, Freedom and moral enhancement, în „Journal of Medical Ethics", 40. 4, 2014, pp. 215-216.

41. Solveig, Magnus Reindal, Disability, gene therapy and eugenics- a challenge to John Harris, în „Journal of Medical Ethics”, 26. 2, 2000, pp. 89-94.

42. O'Mathúna, P. Dónal, Christian bioethics and the Bible, în „Christian Bioethics", 20. 2, 2014, pp. 246-259.

43. Tamar, Sharon, Human nature in an Age of Biotechnology, Maastricht, Springer, 2014.

44. Tarpley, A. Mark, The christian family crisis in the United States and its implications for medical decision making, în „Christian Bioethics”, 7. 3, 2011, pp. 299-314.

45. Zanc, Ioan, Lupu, Iustin, Mureşan, Oana, Bioetica şi provocările ştiinție, în ,Revista Română de Bioetică, vol. 8, nr. 4, 2010.

46. Zane, Ioan, Lupu, Iustin, Mureşan, Oana, Bioetica şi provocările ştiinței, în „Revista Română de Bioetică”, vol. 8, nr. 4, 2010, pp. 3950.

\section{Surse web:}

1. http://www.nickbostrom.com/old/transhumanism.html 